\title{
A Post-Corona Perspective for Smart Cities: 'Should I Stay or Should I Go?'
}

\author{
Saskia Sassen ${ }^{1}$ and Karima Kourtit $2,3,4, *$ (D) \\ 1 Department of Sociology, Columbia University, New York, NY 10025, USA; sjs2@columbia.edu \\ 2 The Faculty of Management, Open University of the Netherlands, 6411 Heerlen, The Netherlands \\ 3 Centre for European Studies, Alexandru Ioan Cuza University, 700506 Iasi, Romania \\ 4 School of Architecture Planning \& Design, University of Technology (UM6P), Benguérir 43155, Morocco \\ * Correspondence: k_kourtit@hotmail.com or karima.kourtit@ou.nl
}

check for

updates

Citation: Sassen, S.; Kourtit, K. A Post-Corona Perspective for Smart Cities: 'Should I Stay or Should I Go?' Sustainability 2021, 13, 9988. https://doi.org/10.3390/su13179988

Academic Editor: Boris A. Portnov

Received: 17 July 2021

Accepted: 19 August 2021

Published: 6 September 2021

Publisher's Note: MDPI stays neutral with regard to jurisdictional claims in published maps and institutional affiliations.

Copyright: (c) 2021 by the authors. Licensee MDPI, Basel, Switzerland. This article is an open access article distributed under the terms and conditions of the Creative Commons Attribution (CC BY) license (https:/ / creativecommons.org/licenses/by/ $4.0 /)$.

\begin{abstract}
This exploratory essay aims to provide a reflection on the possible implications of the COVID-19 pandemic for urban development and to sketch a plausible picture of the urban future. It serves as an introductory contribution to the Special Issue of this journal on 'happy and healthy cities', with particular emphasis on the implications of COVID-19 in pluriform cities. There is no doubt that contemporary cities are growing, and have become more dynamic and crowded. The more people, the bigger the challenges are to manage urban growth and to cope with-and control—density frictions, such as pandemics (e.g., COVID-19). Cities have the task to satisfy the essential needs of many heterogeneous people and to develop appropriate people-based strategies in order to make or keep people happy and healthy. The current COVID-19 disaster is a real urban challenge. The deployment of smart cities' strategies and the use of digital technology tools in order to capture and provide intelligent internal and external online information and communication opportunities may help cities - in active partnership with their residents ('smart citizens' voice') — to manage shocks and disruptions in the urban system. Clearly, cities are dynamic and adaptive organisms with a high resilience capacity. A key question addressed in this paper is whether urban inhabitants may be inclined to move out of the city due to human health threats, or whether intelligent digital technology tools will be able to overcome the current challenges to the 'urban way of life'. The paper argues that modern information and communication technology offers a range of opportunities for a healthy city life, so that the COVID-19 pandemic will most likely not lead to a massive demographic outflow from urban agglomerations to less densely populated areas in particular rural areas. Instead, what is called the 'corona crisis' may cause just a ripple in the permanent dynamic evolution of cities.
\end{abstract}

Keywords: smart cities; happy and healthy citizens; new urban world; resilience; intelligent transformation; COVID-19; data analytics

"There is no single answer to any problem in the city.

The solution comes from a multiplicity of answers"

(Charles Montgomery 2013, pp. 3-16)

\section{Cities in Plural}

The United Nations has in recent years christened the 21st century 'the urban century'. This expression suggests a homogeneous global development of urban agglomerations, but does this imply that the geography of our planet will be characterised by thousands of uniform or monotone cities or endless urban agglomerations? This is clearly not the case. Take two rather arbitrary examples, Amsterdam and Jerusalem. Their population size is not so very different; the same holds for their population density (if the figures on Amsterdam are corrected for water and forest). Both are called 'cities', but this feature does not tell very much about their specific and unique characteristics. They have hardly anything in common. We may posit, in general, that the 'urban century' essentially reflects the 'geography of urban diversity' (see also [1]). Cities are pluriform and heterogeneous 
places, with a great variety in welfare profiles, educational achievements, cultural and ethnic compositions and health conditions. This has implications for the current debate on 'post-corona cities' which centres on the popular proposition that, after the COVID-19 pandemic, a new generic pattern of urbanisation might emerge with lower densities and more dispersion of people.

It is noteworthy that the 'urbanised world' is a dynamic concept. Cities and urban agglomerations have never been a static and tranquil living and working environment, but were always a 'work in progress'. Most cities in our contemporary world have been growing in size and in number, as well as in economic influence [2,3]. Meanwhile, their intrinsic functions were also drastically changing, as a result of digital technology, knowledge orientation, family fragmentation and hyper-mobility. This trend towards a new urban landscape in our world was recently called the 'New Urban World' [4]. This is a general concept which reflects that the urban geography of our world is gradually moving towards an extremely heterogenous patchwork of ever growing cities. This diverse collection of city appearances forms an expanding portfolio of residential choice options for citizens and of locational choices for business.

We also note that current demographic statistics show a structural rise in cross-border migration —often towards cities (see [5])—while at the same time, cities in almost all countries are growing, even in a country with a declining population such as Japan. The COVID-19 pandemic has suddenly created an awareness of possible health risks in cities, especially in densely populated and often poor neighbourhoods. Is it plausible that the structural trend of movement to the city will come to a standstill and that we may expect more dispersed settlement systems in the future? Let us take the giant metropolis of Tokyo as an example. Would it be a realistic scenario if 37 million people in the Greater Tokyo Area were to search for more dispersed locations all over the country? Or would it be more realistic to expect an accelerated suburbanisation trend? Or, perhaps most likely, would the urbanisation trend follow its steady centrifugal pathway from the past decades? This essay offers some food for thought on the above challenges for cities in an urbanised world. It is organised as follows. In Section 2, several megatrends which are shaping and characterising the 'century of cities' are sketched out. Next, Section 3 introduces the smart city concept as an organisational-mainly digital-oriented-vehicle to cope with the manifold challenges of modern cities, while Section 4 is devoted to the potential of cities to create a seedbed for happy and healthy citizens. This is followed up by an exposition on the determinants of 'happy cities' in Section 5, while participatory governance issues are briefly discussed in Section 6. The fundamental characteristics of modern city life-structural urbanisation (Section 2), smart city initiatives (Section 3), the rising need for happy and healthy cities (Sections 4 and 5) and the trend towards citizen-oriented participatory modes in urban governance (Section 6) - culminate in the timely question of how resistant are modern cities against the COVID-19 pandemic (Section 7), seen from the angle of density and proximity. In a concluding section (Section 8), it is argued that cities are always in a state of flux, and that the current pandemic reinforces urban dynamics, but not to the extent that an alternative urban world will arise.

\section{The New Urban World}

The 'New Urban World' [4] is not a paradise. In our 'century of cities', today's world is facing various new 'grand challenges' and opportunities for urban environments, but also possible threats caused by a possible urban stagnation or crisis due to severe negative externalities and disadvantages of urban density [6], as is witnessed by the corona pandemic. In the past century, our planet has experienced a phase of rapid and significant structural transformation of places and a transition to more and bigger cities. However, cities will in the future most likely display a highly differentiated profile in the historical structural process towards an urbanised world. Over the past centuries, we have moved gradually, but certainly, towards the 'New Urban World', a phenomenon which reflects that more and more people have been moving, both domestically and internationally, from rural settlements 
to urban areas, so that urban areas became large but differentiated settlements and the 'new homes of humankind'. Our growing cities provide an added value and an attraction function-as a result of being a highly heterogeneous 'urban jungle' $[7,8]$ — providing new socio-economic opportunities to achieve sustainable and inclusive growth with a strong competitive edge for a heterogeneous urban population. Clearly, the entry into the 'urban century' calls for a new and balanced view on the bubble of mixed urban functionalities, and on the multiplicity of underlying deep forces, dilemmas, extremes and fundamental premises (and how these opposite effects are connected and balance themselves) [9].

Urbanisation is a worldwide phenomenon, with a diversity of appearances. In the Global North, how urbanisation manifests itself is completely different compared with the Global South, where problems of inequality, poverty, health and unemployment are more prominent [10]. A new strategic perspective may help to overcome the oversimplification of complex urban images, and to understand emerging urban paradoxes on shared (public) spaces around us that serve to improve the quality of everyday urban life and to shape the 'soul' of a city.

The phenomenon of dominant-positive and negative-agglomeration forces and ongoing urban transformations has led to unforeseeable structural dynamics of urban life in different geographical regions in the world [7,11]. It has also brought to light a contradiction (maybe even a paradox) in the view that cities are resilient (supported by technological, social and institutional innovation). This contradictory perspective implies, on the one hand, that modern cities may be regarded as essentially 'multi-tasking' agents of synergy with many 'faces' that have become-and remain-an attractive environment for heterogeneous classes of actors and stakeholders with different interests. On the other hand, a negative reputation of cities has started to emerge as being places or common sources of air pollution, overpopulation, poverty, criminality, health crises, pandemics, etc. In their long history, cities have always been operating in a socially conflicting environment. The resulting love-hate relationship between paradoxical extremes of the same urban phenomenon tends to create tensions [12] at a deeper level within cities, and may have far-reaching impacts on the vulnerability of the future urban fabric or even on the 'soul' of the city, possibly resulting in a 'flight' to the suburbs or even rural areas. It is, therefore, important to understand the context, background and content of current urban dynamics.

In the contemporary 'urban century', there is a significant association between the urban paradox of strong centripetal forces-in terms of labour markets, housing, health care, culture, infrastructure, security, educational and career opportunities, economic activity, innovation and social cohesion-and the sometimes negative perception of the quality of life and sustainability of densely populated cities. An intriguing question is whether large urban concentrations-driven by the concept of 'agglomeration economies' [13] will still benefit from a high level of economic growth benefits, if significant changes were to occur in the human perception of desirable settlement systems. Meanwhile, the developments of a continued rise in population and fast urbanisation across most countries and regions might cause major changes in the structure of the urban development potential and growth, which might lead to multiple diseconomies of scale (e.g., inequality, pollution, dissatisfaction, health issues, residential segregation, COVID-19 pandemics, redistribution of traffic flows, traffic congestion, political conflicts) [14-16]. This may have a serious influence on sustainable urban quality of life, on happiness and on liveability in a broad sense (see also what is called 'XXQ' concept—the highest possible quality of urban life; [17]).

Quality of life is a multidimensional, multilevel scale and a complex issue with an enormous variety of (objective and subjective) background features in a diversified urban system. In recent decades, this has received much attention, particularly in regard to health, safety, diseases, employment, green spaces, neighbourhood quality, cultural amenities, visits to parks, social capital, participation in local decision making, overall happiness and urban well-being [18-21]. The process of urban transformation towards sustainability, in the broader sense of being able to support and provide a high environmental and spatial quality of life, raises an important question as to what critical options and elements of 
a city governance capacity are deemed essential to absorb or cope with new city threats or urban perturbations? This also refers also to an 'intelligent transformation' (supported by smart data management) - instead of an 'intelligent lockdown' — as a strategic response to different types of short- and long-run disruptions, crises or shocks, such as the impact and wake of the COVID-19 crisis. This crisis has demonstrated the 'high price of the pandemic' occurring in large, dense and oversized dynamic cities, such as Wuhan, New York, Milan, Madrid, London and Mumbai (just a few examples of high-density cities). These cities have clearly illustrated their vulnerability (and inequality in all aspects of life) to all kinds of hazards, not just the recent pandemic itself. The COVID-19 breakout has had an immense impact on local and national urban systems, and it challenges various domains of socio-economic concerns. This pandemic has already significantly altered our view on urban life (e.g., on physical movements of people, social distancing, work from home, health system, complex policy issues), and has raised a core question: How is it possible to adjust or build our cities and simultaneously manage urban dynamics at all relevant scale levels in combination with an intelligent transformation, so as to cope with-and to respond smartly to-current and future threats? What are the feelings, perceptions, attitudes and behaviours of the 'citizen' in periods of perturbations such as the pandemic?

\section{Will the Smart City Raise Its Hand?}

If cities are to be the 'home of man' [22], they need to be well maintained. Threats such as the COVID-19 pandemic need smart responses. Over the past decade, smart cities have gained much popularity among urban economists, planners and policy makers, but do smart cities also deliver better outcomes in times of a pandemic? Clearly, smart cities call for an intelligent mobilisation of all available urban digital and knowledge resources and are supposed to create an accelerated socio-economic added value, including in periods of a crisis. Fields where generally high socio-economic benefits from smart city policy are to be expected are, amongst others:

- Environmental and health transition (changes in agro-food chains, rise of new forms of urban agriculture, emergence of a bio-based economy, design of novel nutrition strategies, etc.), which will fundamentally change the traditional urban-rural landscape in the country from an economic, social, cultural, agricultural and technological perspective (cf., the 'local for local' slogan).

- Resource and energy transition (new materials technology, zero-waste cities, car-free settlements or districts, intelligent public space management through smart-mobility plans, demand-oriented street light management or smart urban traffic light systems), all of which will call for new forms of urban land use planning, facility management, etc. (cf., the idea of a 'circular economy').

- Socio-demographic and spatial transition (rise in one-person households, emergence of the double ageing process, ethnic tensions, politically unstable districts, new forms of caregiving, etc.), which will lead to new urban population structures and related management challenges of the city as a 'place4all' (cf., the citizen science approach).

- Cultural and community transition (need for cultural identity, threats to community feeling due to alienation, rise of urban 'crime districts', destruction of public space in cities as a place for social life), all of which will challenge the city's social capital advantages.

We note, however, that the positive smart city conundrum has also brought to light that in many cities the sky-rocketing expectations about smart city effects have not materialised. Chicago calls itself a smart city, but does it excel in urban safety or income inequality? Athens is another smart city, but is it able to solve its congestion and air pollution problems? How is it possible that a city such as Beijing, which is able to control the movements of its citizens, is paralysed when it comes to coping effectively with the smog during the summer? Apparently, there is a significant gap between the myth of the smart city and its actual performance as a healthy or happy city. This is all the more striking, when taking into consideration the range of new digital opportunities for the enhancement of urban 
liveability and health conditions, including in cases of a shock. Examples of potential new developments are:

- Urban data analytics (e.g., urban data platforms or warehouses, social media monitoring, shared data warehousing, big data metrics);

- Advanced information management techniques (e.g., visualisation techniques, satellite systems, sensorisation, smart urban dashboards, 3D event technologies, morphometric analysis);

- Public space management (e.g., interactive neighbourhood plans, geoscience technology, BIM applications, urban 'body and soul' analysis, design of environmentally benign and safe districts, multi-actor MCA models);

- Online safety procedures (e.g., camera-surveillance of public spaces, advanced data management as a preventive tool against criminality, smart balance between safety measures and privacy protection, urban disaster management).

- Social technology applications (e.g., AI, urban imaging, city Imagineering, urban robotics in, for example, the care sector, logistics and blockchain applications).

- New forms of local e-democracy (e.g., innovative citizen participation, electronic procurement procedures, early warning systems ('dashboards') for maintenance activities).

While [23] asks the intriguing question whether the 'smart city will stand up', as yet, the success stories of smart cities are rather limited. This is particularly painful in the current age of the COVID-19 pandemic. Despite the great potential of 'home offices', it turns out that many people prefer to be physically present-at least most of the time-at their workplace. Another example: there are many digital ways (through smart apps) to find out whether the smart device owner has been in the close vicinity of someone who was corona-infected, but its actual use and positive impact in the battle against COVID-19 is still questionable. Besides, there are many ways to design and use electronic corona passports, so that free travel would be possible with acceptable risks, but the digital road to their global introduction is paved with many administrative and digital stumbling blocks. In the current corona times, it is not even proven that smart digital cities have a lower infection rate than 'standard' cities. The urban fabric is apparently a complex arena for living, working, health and leisure, especially in corona times.

Smart cities-with smart people-are not crafted in stone and are not isolated islands in a fixed urban 'space-economy bubble'. They are living intelligent organisms with complex, dynamic and interacting spatial 'bodies' providing a mix of multiple opportunities, dreams, social interaction options and alternatives and strategic and personal choices to make, in a dynamic, sometimes global network society [24]. Clearly, the strategic role of modern cities is to be an urban escalator of a mixed package of continuous and limitless socio-economic opportunities, alternatives, promises and choices for people. This is materialised in the context of providing a future perspective and sustainable wellbeing (including good health and happiness), in what is called the 'city of opportunity' $[25,26]$. In addition to the 'city of opportunity' perspective, its contents (potential drivers and instruments) may also, at the same time, elevate and enhance the appreciation, feeling, loyalty, attachment and pride of residents for their city.

\section{Happy and Healthy Citizens}

Cities have always provoked mixed feelings. If we take for granted the urban paradox of the 'goods' and the 'bads' of the city, the need arises for a strategic sustainable re-orientation and repositioning of cities in order to manage and to govern smart actions and solutions to enhance cities' liveability. This new way of thinking aims to tackle urban challenges, enhance the cities' facilities and infrastructure to provide a more efficient modus operandi and leverage technologies (e.g., AI, ML, (big) data analytics, IoT) with the intention to make cities smarter and liveable, create intelligent environments (e.g., embedded ICTs, data sharing), elevate the quality of life and ensure that human settlements all over the world are a 'place4all'. This ideal has also promoted the introduction and popularity of the smart cities concept, with its main mission to favour and streamline intelligent governance so as to provide a better quality of life for people, ranging from governmental 
speed of responsiveness to effective strategic actions on pandemics, health, the economy, the needs of the people (happy and healthy citizens) or societal crisis.

Putting people first as a 'landmark protocol', smart cities stand better chances at earning the accolade of being most liveable and loveable, and at becoming healthier and happier cities through a joined-up and collaborative partnership with the people (see also [27]. The implementation of smart city initiatives with the involvement of 'end-users' and 'co-producers', and with their specific needs and values in mind, reminds us that digital technology is not a goal in itself, but rather an enabler of providing internal and external up-to-date information [28]. Smart information enhances the quality of location-based decision-making and data-driven spatial strategies in order to maximise the achievement of a sustainable happy and healthy city. To build and develop further healthy and happy cities for people, a myriad of factors must capture and represent a balanced mix from a multifaceted perspective on future urban development in order to attain the highest possible level of urban quality of life ('XXQ').

While there is great heterogeneity among people and their needs in any complex urban fabric, this complex multi-actor system also contains a great pluriformity in the political and socio-economic arena, including differentiated health outcomes in pandemic times, with varying consequences for sustainable citizen well-being and urban competitiveness. It is clear that the economic arena needs to be explained and governed from a broader perspective, in addition to standard economic indicators. Clearly, the assessment of people's quality of life-mainly by non-economic indicators (such as the Human Development Index (HDI) and the Happy Planet Index (HPI)) - plays an important role in assessing urban liveability [29-31]. Therefore, we need to adjust our mindset on how we think about cities and how to foster health and well-being through smart governance, innovation, knowledge sharing, intelligent empowerment and citizen participation in inducing effective actions for tackling inequalities and common global pandemic challenges, while pursuing an equitable health coverage of people who live, play, love and work in our cities.

It is important, therefore, to trace in a balanced way the drivers of the achievement levels of critical factors and (pre-)conditions that are of paramount importance in realising essential and valuable possibilities (see also the capability concept: [32-35]) and in creating happier and healthier cities and regions, with a view to maximise the aforementioned XXQ. This means that cities' XXQ strategies should be composed or decomposed into two substances, namely, relating to their 'body' (physical characteristics) and 'soul' (intangible and emotional attractiveness) features, which are seen as the universal drivers for 'city love' (see [36]). To serve the needs of people and make or keep them happy and healthy, a strong bridge needs to be built between policies, strategies and the involvement and empowerment of key stakeholders, including the citizens. This is necessary to create a transparent and strong alignment and to manage and understand the complexity of the whole urban system so as to keep improving its resilience (achieving 'peak performance') and the daily or strategic decisions of all urban stakeholders and avoiding meltdowns ('intelligent lockdowns') of the urban system (due to, e.g., COVID-19 restrictions), all in order to harness the sustainability of happy and healthy cities and their people. Therefore, it is important to encapsulate and reflect the well-being of citizens in any resilience strategy. The emotional drivers, perceptions, values, attitudes and behaviours of people regarding local quality of life are critical parameters for successful intelligent transformations and effective strategies in urban systems, for the adoption of digital technology and information and for related actions focused on citizens' high satisfaction with their living environment (i.e., 'city love').

Human (physical and mental) health is one of the most critical factors for individual and societal happiness and well-being [37-39]. Clearly, income and wealth are-in the economists' perspective-also important drivers of human well-being. It is generally accepted that these two classes of determinants-health and wealth-are together a sine qua non for the level of contentment in society. In recent years, much attention has been given in the social sciences to the identification and impact assessment of a 'happy, healthy 
and wealthy' society. It is noteworthy that a healthy society may relate to both physical and mental health conditions, and consequently, both physical characteristics and favourable spiritual conditions may contribute to a healthy society [40]. Similarly, a wealthy society does not only relate to income and prosperity, but also to intangible factors such as job satisfaction and a high quality of life. It should be noted that the social sciences have in recent years adopted a broad perspective on the interface between health conditions and economic conditions in a wider geographical-environmental context (see, e.g., [41]).

It is often argued in the literature that the operational definition and the practical measurement of human health and happiness are fraught with many difficulties [42-45] (e.g., in terms of objective medical data or self-reported health and happiness statements). The same holds true for the definition and measurement of welfare, e.g., in terms of GDP or jobs, or welfare satisfaction. In both situations, the geographical-environmental conditions play a clear role. It should be noted that welfare disparities in cities play a prominent role in the urban performance regarding happiness and sustainability. Refs. [46,47] has argued that many cities are facing an urban crisis, as lower-income groups are driven out of the city.

Place-based quality of life impacts human health and happiness, while residential location is a determinant of healthy life and satisfaction conditions. Of course, the analysis of such patterns in cities is an empirical challenge, due to the lack of appropriate data systems and the presence of complex causality relationships. This also applies to the assessment of the effects of external background conditions in cities (both the built environment-the 'body' - and the social living climate-the 'soul') and the experienced quality of life (happiness or city love) in relation to the of residents' or citizens' appreciation of their city or urban neighbourhood. Such studies call for both sufficient databases (e.g., 'big data') and advanced modelling and statistical methods (see [48]) (e.g., data mining, machine learning, spatial autocorrelation methods). This is a rapidly emerging research field, in combination with emerging digital technologies that, as spatial elevators may help to enhance and lift cities to become smart and dynamic engines for wealth creation and global competitiveness (see, for instance, [2,49-53]). Such data-analytic approaches are a sine qua non for the measurement of city love, including in periods of a pandemic. This is further discussed in the next section.

\section{City Love: Body, Soul, Brains}

'Cities4people' is a popular urban paradigm. The city of opportunities and dreams may, however, only exist for some 'happy few', but others may have antagonistic feelings about the city. It is not so easy to love a city. In addition, a city itself needs love. As mentioned above, a city is sometimes crowded, chaotic, noisy, polluted and a threat to well-being and health, where several people may be at a disadvantage to varying degrees. Clearly, people are using their voice in various problematic situations and express their complaints or dissatisfaction by aggressive honking sounds and words in the city streets. Yet, the majority of the people do not plan to leave the city, but are prepared to sacrifice even quite a lot in order to live in the city, since over the years, they may ultimately find the city over the years more appealing than ever before.

The city of many possibilities, facilities and amenities has created a clear and distinct feature whereby people might find themselves hankering for a few things that make the city attractive. Hence, the pressing question is: Should I stay or should I go? This dilemma was, in particular, raised strongly at the beginning of the COVID-19 pandemic. When the pandemic hit many cities, people became worried about becoming infected or ill, having to live in isolation, being subjected to quarantine restrictions, facing supply-chain interruptions, experiencing a collapse of the medical system, risking a disruption on the supply side of the tight real estate housing market, etc. Some people-who could afford to do so-tried temporarily to stay out of the city, e.g., in summer houses, luxury hotels or Airbnb accommodation (with good hygienic conditions at least), so as to live-perhaps at higher prices—for some time in relatively safe environments (see, e.g., [54]). The question 
arises: Will these people go back to the city and, if so, when? Or will more people follow? At the very least, people will ultimately find a place in their perceived 'home', wherever that may be.

According to [55], cities do matter and are very important for the world's healthy socio-economic future. Furthermore, these authors endeavour to point out that cities are often irresistible powerhouses of faith, belief and desired sustainable development. From the literature (see, e.g., [56-60]), we observe many effective and beneficial advantages of the city due to increased levels of engagement, social density, learning (experience and innovations from others), high interaction and cultural proximity benefits. These external benefits (received from co-location and proximity) are translated and transferred to citizens, workers, businesses and industries, while they also become part of the urban mechanism as a contributor to 'agglomeration economies'; in fact, the conventional notion of 'agglomeration economies' was already debated centuries ago by [61,62]. This concept may reinforce an increase in local socio-economic systems, technological and information issues, confidence in the foreseeable future, strategic positions of cities in an arena of dynamic competition and unrivalled intelligent transformations. Thus, due to its agglomeration advantages, the city has a lot to offer and generally has extensive systems for good schools, culture, nightlife, health care systems, housing, sanitation, land use, transportation, etc. So, will the conventional agglomeration advantages then be overruled by the negative density perceptions during corona times?

The city is consistently the best place for producing creativity, innovation, knowledge, great inventions, expertise, cultural (common) goods, a large labour pool, networks, advanced technologies, digital information, etc. So, the city is potentially the seedbed for the 'new home of humankind' [22], which may provide an attractive urban ambiance for 'creative and innovative minds' with challenging socio-economic opportunities and dreams. So, is there a balance between urban scale advantages and urban health disadvantages?

In his book, entitled The Triumph of the City, Ref. [63] posits that 'cities are people' and argues that cities rise and decline due to the fact that it is the people themselves who make great and competitive cities and develop strategic capacity building with ups and downs which are critical to success or failure. Thus, when many people live increasingly in a very high-density setting, in a demarcated geographical area, this will lead to the formation of an urban space and it will even become a desirable and promising geographical settlement system. Thus, a central proposition is that people love cities. However, cities also need people, with a view to advancing health and well-being and stimulating socio-economic vitality in combination with meeting the interests, needs and values of a multiplicity of stakeholders and ensuring people's high satisfaction and expectations. As [64] has already advocated, it is: 'to them, not buildings that we must fit our plans'. Her message emphasises once more the need to care for all income groups in the city.

As mentioned above, love for the city encompasses 'body' and 'soul' features that illustrate the image of urban attractiveness and quality of life that various people (e.g., residents, firms, visitors) have for their living environment. The quality of life (physical and immaterial) is the key for urban love (including happiness, health and well-being). To shed a more systematic light on the urban attractiveness needs a better understanding of the city as a 'complex' constellation [65] that meets the needs of a heterogeneous group of people with an extreme diversity in terms of their attitude to education, creativity and innovativeness. Different disciplines have a different understanding of the nature and conceptual cornerstones of attractiveness, while the operational assessment of urban attractiveness depends on objective versus subjective evaluation methods in various urban disciplines. This means that an unambiguous perspective on the future of our cities is often problematic.

The portfolio of the (basic) urban ingredients, such as public facilities, social conditions, advanced digital technologies, historical-cultural identity, etc., is enormous and wideranging. This should be encapsulated in a competitive socio-economic and sustainable development and in a smart city strategy, so as to reinforce the complex multidimensional urban quality of life (the XXQ outcomes), which is essentially based on place-making theory 
on urban areas [66-76]. This calls for a clear and quantitative approach to identifying cities' attractiveness characteristics based on smart communities' voices and residents' perceptions of urban quality and their affinity with urban life. This also needs the development of an operational framework for assessing the citizens' appreciation, in terms of residents' love for their city, based on 'body' and 'soul' elements (e.g., [64,77-84]).

In a recent publication of [36], the authors show that the body and soul characteristics are both significant, while soul aspects show a relatively stronger impact in the production function of the love for the city. The question here arises: Will the smart city succeed in turning the love-hate relationship for the city into a positive balance, including in corona times? Such a reconciliation of conflicting feelings for the city may come about in several ways. People are more digital and may be able to live more easily outside of the city. The consequences of these movements can manifest themselves in different ways: enhanced urbanisation (e.g., mammoth cities, dense urban agglomerations), return to rural areas or continued suburbanisation or poly-nuclear developments (see e.g., China, USA, Japan, Brazil, India, etc.). In general, however, it seems as if most people prefer to live in a human-scale 'urban village' or a place that has good connectivity with the city (a place 'full of neighbours') (see, e.g., $[64,77,85-90])$. Cities also house a wealth of social capital, as is described in Section 6.

\section{The Masters' Voice in Smart Cities}

Smart cities are not a goal in themselves; they have to serve the citizens' well-being. A smart city is not meant to be a utopian dream, but a realistic policy framework instrument, where the strong support and high involvement of various important stakeholders and responsible citizens are essential to promote sustainable development practices, including sustainable investments, in order to enhance the quality of life [91]. Putting citizens and various (social) groups in the spotlight of environmental and sustainability ambitions in a smart city ecosystem may help to operationalise an original and actionable bottom-up policy support system for the successful implementation of smart and intelligent city initiatives at local level. It adopts a 'Quadruple Helix' approach in which-in addition to governments, the knowledge sector and industry-citizens and civic organisations are regarded as core players in sustainable governance and policy. The pivotal perspective of the smart city ecosystem, supported by ICT, is that the 'smart voice' of citizens (regarding awareness, behaviour, practices, values, preferences, civic engagement) resounds in their roles as key actors in a smart societal transformation towards a resilient society and economy, in particular when a new vision of the 'post-corona' city is needed. Citizen engagement and commitment form the unifying element, with a clear interdisciplinary resilient orientation, at the interface of the local, regional and national governance systems in supporting the development of high-quality and sustainable places [92,93]. This approach is instrumental in tracing the willingness of citizens, together with bottlenecks and resilience factors, and in adapting their behaviour toward more favourable XXQ outcomes.

The 'smart voice' approach is a citizen science-oriented, sustainable management and actionable response of urban areas and their stakeholders with shared responsibility, on the basis of various (real-time) evidence-based data sources, information tools, digital technologies and learning mechanisms that provide an explicit voice by and for citizens in order to advocate and anticipate 'grand challenges'. Its purpose is based on enhancing actionable quality-of-life ambitions by addressing, in a bottom-up way, cognitive and attitudinal challenges and environmentally benign citizens' responses. The 'smart voice' is a challenging transition from science for people towards citizen science [94-97].

Citizen-oriented science implies the complex active involvement of the citizen, by participating in the scientific process itself through individualised observing, gathering or processing data [98-100]. Citizens can be engaged in smart city ecosystems in many ways [101] using interactive digital tools as communication and learning platforms to create, for instance, a better understanding and awareness of pandemics, sustainable responses and behavioural changes in a bottom-up way. From this perspective, this approach is instrumental in tracing the willingness of citizens, zooming in on the perceptions and 
opinions of citizens, while considering bottlenecks and resilience factors, and in adapting consumption and people's production decisions and their behaviour to more positive XXQ outcomes. In addition to bottom-up citizen science approaches, incentive motivations form the core component of citizen science through the use of behavioural nudges and affective experimental manipulations in environmental and neighbourhood actions. The challenge here is to build a merger of citizen science-inspired experimental approaches at a decentralised territorial level with user-friendly digital technology devices and applications, so as to create a higher acceptance and efficiency in achieving a better quality of life for people (e.g., happy and healthy citizens achievements), with the involvement of various stakeholders in the urban system. That said, we now address the question whether COVID19 may be a game changer in the historical trends of more urbanisation, more cities and bigger cities.

\section{The Corona Game Changer: Density and Proximity in Smart Cities}

The COVID-19 pandemic has caused a disruption in city life. Clearly, urban agglomerations have never developed in an undisturbed and uncontested environment without any threats or shocks. In the long urban history of our world, many cities have gone through major disruptions, caused by fires, earthquakes, bombardments, wars, floods, tsunamis, hurricanes, technological disasters and pandemics. The predominant advantage of cities, viz., the presence of geographical concentration and urban agglomeration benefits, appears to be also a critical vulnerability in a case of unexpected shocks. Nowadays, proximity and density are apparently a source of major devastating health impacts that affect the entire urban social fabric. Notwithstanding the high social and economic costs of urban disasters, cities all over the world have, in general, turned out to be extraordinarily resilient in coping with such shocks. The 9/11 attacks on the Twin Towers have not led to any significant flight of people from New York to the countryside. Likewise, Hurricane Katrina-despite its far-reaching disruptive effects-has not led to a structural decline of New Orleans. German cities bombed during WWII have shown a remarkable recovery pattern and have not suffered from an outflux to the countryside $[102,103]$.

Would the current corona pandemic cause a historical breakthrough in the centurieslong trend towards more urbanisation? Based on historical facts and in the light of the above-mentioned sketched force field of cities, it does not seem likely that COVID-19 will dramatically alter the urban mode of life. A main reason is that many urban inhabitants are 'captives' who have no chance to move to other, more healthy places and are thus forced to live in high-density neighbourhoods. Admittedly, there may be a small group of people (e.g., the elderly) who are looking for a healthier living environment outside major city centres. However, a mass de-urbanisation movement is extremely improbable, as the magnetic force of cities has not been affected by the corona pandemic (see also [104,105]) In the eyes of many people, the city is - and will remain - a top notch place to live, where you find inspiring culture, impressive arts, unbelievable entertainment, fine cuisine and walkable inner cities (e.g., [106]). Of course, urban density might temporarily be seen as a serious drawback for a healthy living environment, but that is why, already for many decades, the suburbs have been built. At best, modest adjustments in the urban pattern may be expected. Two urban development trajectories may be imagined in the post-corona era:

- A higher interest in suburban ways of living, so as to avoid the health diseconomies of inner-city density and proximity; this is, however, essentially a continuation of pre-corona suburbanisation patterns and not a radically new movement.

- An intensive effort to strengthen intelligent urbanism, in which planning, management and the governance of cities and urban areas is put in the context of a smart city policy that seeks to stimulate XXQ on the basis of digital technology devices for human health, but also for heritage conservation, mobility management, circular city implementation and urban re-generation.

It is indeed noteworthy that, as yet, no city in the world has cancelled its plans to build more high-rise buildings in its city centre. COVID-19 is, thus far, not an evident 
game changer in urban development and policy. It seems that the motto of UN Habitat, articulated in 'The City We Need' (2016), also holds for the (post-) corona age: "The battle for a more sustainable future will be won or lost in cities". The battle of inhabitants against the corona virus will apparently take place in the city, by the smart use of intelligent urbanism, and not outside in the countryside. From a technological perspective, an isolationist or nomadic lifestyle might be feasible, but from a social science perspective, it is not likely that people will give up their function and role as a 'homo socialis'.

\section{Will the Post-Corona City Ever Exist?}

The city is a kind of reservoir-people can both easily enter and easily leave a city in order to move to a suburban or rural area, provided they have the financial means to do so. People always have to make compromising choices, and to follow priorities and decisions regarding their well-being, health and happiness, thereby impacting current and future cities. People want their 'frontdoor in the city centre and a backdoor in the forest' ('love the city you hate').

The current debate on 'The New Urban World' calls for a critical debate that may play an important role in finding out why people would choose to stay or leave the city, as in the urban to rural flight during the beginning of the COVID-19 crisis, but also events such as the 9/11 attacks, the Lehman Brothers bankruptcy in 2008, and so forth. There is a permanent centripetal and centrifugal movement to and from the city. As things stand now (based on historical facts), most cities have always become bigger over the past centuries (see $[104,105])$. To keep pace with the structural transformation of settlement patterns of people and with persistent and rapid urbanisation, smart cities need to adjust themselves to new circumstances (using new technology, 'digitisation', data, information, vision) and develop effects and response strategies in collaborative partnership with citizens by 'putting people first'. Consequently, the success of well-designed XXQ strategies to strengthen intelligent urbanism has become an essential element to launch foundational transformations at different relevant scale levels of the urban fabric [104].

In this context, resilience capability building-in a transparent and systemic collaboration with the involvement of 'end-users' and 'co-producers' (people)—may power an intelligent transformation of cities, using new technologies and data analytics. In turn, making smart governance effective, with jointly undertaken strategic efforts—by continuously anticipating changing circumstances, urban paradoxes, pandemics, crises and shocks, and by decoding and converting threats into opportunities-is helping to change and to focus their urban development trajectories on crucial value-building elements in order to maximise the achievement of a sustainable happy and healthy city.

We also note that there is a need for strict intelligent governance systems and response mechanisms to avoid any kind of 'policy lockdown'. Furthermore, to create a full-scale flexibility and a smart adaptability to these changes, we need instantaneous-pandemic and socio-economic-interventions and responses from effective policy and governance in order to cope with the supply and demand shocks and responses in the COVID-19 pandemic, equity in healthcare utilisation or panic behaviour responses ('non-social behaviour') during disaster and calamities. This may help in providing user-oriented decision tools to develop preventive strategies (e.g., security control) and interact under (un)certain future conditions and interruptions. In particular, when taking into consideration the present pressing concerns, it may also help to address current and future urban complications and urban paradoxes on the basis of 'city intelligence'. This helps to build strong urban capacity network linkages and effective resilience strategies so as to make a better risk assessment in the face of uncertainty in different ways and levels. Admittedly, the access to 'city intelligence' is unequally distributed, so that any corona-inspired dynamics will reflect socio-spatial disparities in cities.

Clearly, strengthening citizen empowerment and partnership is crucial for building an intelligent 'resilience agglomeration' to launch 'foundational transformations' [103]; this calls for solid and comparable databases (and underlying metrics) on sustainable 
development to identify a multiplicity of answers in order to develop effective policy intervention tools and related intelligent solutions [107-109].

There is a need for a data analytics orientation on the conditions (drivers and effects) that govern human health and happiness (including spatial movements that support a healthy and happy lifestyle). In addition to a more general econometric and statistical analysis of the spatial health and happiness patterns concerned, the challenge nowadays is also to develop a new framing for the UN Sustainable Development Goals (SDGs) in relation to city development and profiles (e.g., for spatial mobility, environmental quality measurement, health care, etc.).

As mentioned at the beginning of this contribution, cities are evolutionary and adaptive organisations. In the history of humankind, people have been very smart in coping with shocks so as to survive. Cities appear to have the DNA of a phoenix and will most likely always overcome threats, including the threats of the corona virus. People born with 'urban genes' will most probably find a home in an urban area, despite temporary inconveniences or disasters. We refer here finally to [110]: "One of German-born geographer Ernest George Ravenstein's original laws of migration posits that people are motivated to move by economic opportunity. Broadly speaking, we go where the jobs are. Real-life experience, however, confirms that when your family lives in your town, you are less likely to go after a new job out of stage, even when it's better for you financially" (p. 69). This quotation is also valid in corona times. Cities have strong centripetal strength, and it is highly unlikely that the present COVID-19 pandemic will cause such strong centrifugal forces that the ongoing urbanisation during the past centuries will reach a tipping point. Social and spatial disparities in cities are rather robust, and will be mirrored in any response to the corona crisis. The good news is that digital technology in smart cities will help to mitigate the human health challenges in large urban agglomerations.

Author Contributions: S.S. and K.K. contributed equally. All authors have read and agreed to the published version of the manuscript.

Funding: This research received no external funding.

Institutional Review Board Statement: Not applicable.

Informed Consent Statement: Not applicable.

Data Availability Statement: Not applicable.

Acknowledgments: Karima Kourtit acknowledges the grant from the Axel och Margaret Ax:son Johnsons Stiftelse, Sweden. Karima Kourtit also acknowledges the grant from the Romanian Ministry of Research and Innovation, CNCS-UEFISCDI, project number PN-III-P4-ID-PCCF-2016-0166, within the PNCDI III" project ReGrowEU-Advancing ground-breaking research in regional growth and development theories, through a resilience approach: towards a convergent, balanced and sustainable European Union (Iasi, Romania).

Conflicts of Interest: The authors declare no conflict of interest.

\section{References}

1. Sudjic, D. The Language of Cities; Penguin: Milton Keynes, UK, 2016.

2. Sassen, S. The Global City; Princeton University Press: Princeton, NJ, USA, 1991.

3. Glaeser, E.; Kourtit, K.; Nijkamp, P. (Eds.) Urban Empires; Routledge: New York, NY, USA, 2020.

4. Kourtit, K. The New Urban World; Shaker: Aachen, Germany, 2019.

5. Kourtit, K.; Newbold, B.; Nijkamp, P.; Partridge, M. The Economic Geography of Cross-Border Migration; Springer: Berlin, Germany, 2021.

6. Sassen, S. Challenges Facing Global Cities in the 21st Century; International Herald: 2008. Available online: http:/ / www.saskiasassen. com/PDFs/publications/Challenges-Facing-Global-Cities.pdf (accessed on 30 November 2008).

7. Sassen, S. The Global City: Introducing a Concept. Brown J. World Aff. 2005, 11, 27-43.

8. Stiglitz, J.E. Making Globalization Work; W.W. Norton and Company: New York, NY, USA, 2006.

9. Frost, P.J.; Kaiser, E.F.; Quinn, R.E. Beyond Rational Management: Mastering the Paradoxes and Competing Demands of High Performance; Jossey-Bass: San Francisco, CA, USA, 1991.

10. Shaban, A.; Kourtit, K.; Nijkamp, P. India's Urban System. Sustainability 2020, 12, 2941. [CrossRef] 
11. Nijkamp, P. Regional Development and Urban Dynamics Seminal Studies. In Regional and Urban Economics; Capello, R., Ed.; Springer: Berlin, Germany, 2017; pp. 305-312.

12. Briskin, A. The Stirring of Soul in the Workplace; Berrett-Koehler: San Francisco, CA, USA, 1998.

13. Quigley, J.M. Urbanization, Agglomeration, and Economic Development; Berkeley Program on Housing and Urban Policy; University of California: Berkeley, CA, USA, 2008; Available online: https://escholarship.org/uc/item/6tf2s100 (accessed on 30 September 2008).

14. Barufi, A.M.; Kourtit, K. Agglomeration Forces in Smart Cities. In The Rise of the City—Spatial Dynamics in the Urban Century; Kourtit, K., Nijkamp, P., Stough, R., Eds.; Edward Elgar: Cheltenham, UK, 2015; pp. 33-54.

15. Kourtit, K.; Nijkamp, P.; Stough, R. (Eds.) The Rise of the City: Spatial Dynamics in the Urban Century; Edward Elgar: Cheltenham, UK, 2015.

16. Rodríguez-Pose, A. The revenge of the places that don't matter (and what to do about it). Camb. J. Reg. Econ. Soc. 2018, 11, 189-209. [CrossRef]

17. Nijkamp, P. XXQ Factors for Sustainable Urban Development: A Systems economics View. Rom. J. Reg. Sci. 2008, 2, 325-342.

18. Easterlin, R.A.; McVey, L.V.; Switek, M.; Sawangfa, O.; Zweig, J.S. The Happiness-Income Paradox Revisited. Proc. Natl. Acad. Sci. USA 2010, 107, 22463-22468. [CrossRef]

19. Marans, R.W.; Stimson, R. (Eds.) An Overview of Quality of Urban Life. In Investigating Quality of Urban Life; Social Indicators Research Series; Springer: Dordrecht, The Netherlands, 2011; Volume 45.

20. Deaton, A. The Great Escape; Health. Wealth: And the Origins of Inequality; Princeton University Press: Princeton, NJ, USA, 2015.

21. Burger, M.; Hendriks, M.; Hoogerbrugge, M.; Morrison, P.S. Urban-Rural Happiness Differentials across the World. In World Happiness Report; Helliwell, J.F., Layard, R., Sachs, J., De Neve, J.E., Eds.; Sustainable Development Solutions Network: New York, NY, USA, 2020; Available online: https:/ / worldhappiness.report/ed/2020/urban-rural-happiness-differentials-across-theworld/ (accessed on 30 March 2020).

22. Ward, B. The Home of Man; Norton: New York, NY, USA, 1976.

23. Hollands, R.G. Will the real smart city please stand up? City 2008, 12, 303-320. [CrossRef]

24. Neal, Z. The Connected City; Routledge: New York, NY, USA, 2012.

25. Nijkamp, P. The 'Resourceful Region', A New Conceptualisation of Regional Development Strategies. J. Reg. Res. 2016, 36, 191-214.

26. Kourtit, K.; Nijkamp, P.; Haas, T. The City of Opportunity: Designing Cities4People. In International Handbook on Cities and Networks; Rozenblat, C., Neal, Z., Eds.; Edward Elgar Publishing Ltd: Cheltenham, UK, 2021; pp. 273-293.

27. Caragliu, A.; DEL Bo, C.F.M.; Nijkamp, P. Smart Cities in Europe. J. Urban Technol. 2011, 18, 65-82. [CrossRef]

28. Kitchin, R. Data-Driven, Networked Urbanism. Social Science Research Network (SSRN). Available online: http:/ / papers.ssrn.com/ abstract $=2641802$ (accessed on 30 September 2015).

29. Helliwell, J.F.; Huang, H.; Wang, S. The Social Foundations of World Happiness. In World Happiness Report; Helliwell, J., Layard, R., Sachs, J., Eds.; Sustainable Development Solutions Network: New York, NY, USA, 2017.

30. Marlet, G.; van Woerkens, C. Atlas voor Gemeenten; Geluk, VOC Uitgevers: Nijmegen, UK, 2017.

31. Roessler, J.; Gloor, P.A. Measuring happiness increases happiness. J. Comput. Soc. Sci. 2021, 4, 123-146. [CrossRef]

32. Sen, A. Equality of What? In Tanner Lectures on Human Values; McMurrin, S., Ed.; Cambridge University Press: Cambridge, UK, 1980; Volume I, Available online: https:/ / www.ophi.org.uk/wp-content/uploads/Sen-1979_Equality-of-What.pdf (accessed on 30 May 1979).

33. Sen, A. Capability and Well-Being. In The Quality of Life; Sen, A., Ed.; Clarendon Press: Oxford, UK, 2012 ; pp. $30-53$.

34. Gardoni, P.; Murphy, C. Recovery from natural and man-made disasters as capabilities restoration and enhancement. Int. J. Sustain. Dev. Plan. 2008, 3, 317-333. [CrossRef]

35. Robeyns, I. The Capability Approach, The Stanford Encyclopedia of Philosophy, Summer 2011 ed.; Zalta, E.N., Ed.; 2011; Available online: http:/ / plato.stanford.edu/archives/sum2011/entries/capability-approach (accessed on 22 October 2015).

36. Wahlström, M.H.; Kourtit, K.; Nijkamp, P. Planning Cities4People-A body and soul analysis of urban neighbourhoods. Public Manag. Rev. 2020, 22, 687-700. [CrossRef]

37. Diener, E. Subjective Wellbeing: The Science of Happiness and a Proposal for a National Index. Am. Psychol. 2000, 55, 34-43. [CrossRef]

38. Frey, B.S.; Stutzer, A. Happiness and Economics; Princeton University Press: Princeton, NJ, USA, 2002.

39. Diener, E.; Scollon, C.N.; Lucas, R.E. The Evolving Concept of Subjective Well-Being: The Multifaceted Nature of Happiness. In Assessing Well-Being: The Collected Works of Ed Diener; Diener, E., Ed.; Springer: New York, NY, USA, 2009; pp. 67-100.

40. Biswas-Diener, R.M. Material Wealth and Subjective Well-Being. In The Science of Subjective Well-Being; Eid, M., Larsen, R.J., Eds.; Guilford Press: New York, NY, USA, 2008; pp. 307-322.

41. Kourtit, K.; Nijkamp, P.; Wahlström, M.H. How to make cities the home of people-A 'soul and body' analysis of urban attractiveness. Land Use Policy 2020, 2020, 104734. [CrossRef]

42. Veenhoven, R. Conditions of Happiness; Reidel; Springer: Dordrecht, The Netherlands, 2020.

43. Arrigo, U.; Sordelli, M. Alcuni Aspetti Problematici nel Dibattito su 'Happiness and Economics'. In Proceedings of the XVI Conference of Società Italiana di Economia Pubblica, Pavia, Italy, 7-8 October 2004; Available online: http:/ /www.unipv.it/ websiep/wp/371.pdf (accessed on 30 October 2004). 
44. Kahneman, D.; Krueger, A.B. Developments in the Measurement of Subjective Well-Being. J. Econ. Perspect. 2006, $20,3-24$. [CrossRef]

45. Frey, B.S.; Luechinger, S. Concepts of Happiness and their Meaurement. In Jahrbuch Ökologische Ökonomik; Marburg, S., Ed.; Springer: Berlin/Heidelberg, Germany, 2007; pp. 219-237.

46. Florida, R.; Mellander, C.; Rentfrow, P.J. The Happiness of Cities. Reg. Stud. 2013, 47, 613-627. [CrossRef]

47. Florida, R. The New Urban Crisis: How Our Cities are Increasing Inequality, Deepening Segregation, and Failing the Middle ClassAnd What We Can Do About It; Basic Books: New York, NY, USA, 2017.

48. Voukelatou, V.; Gabrielli, L.; Miliou, I.; Cresci, S.; Sharma, R.; Tesconi, M.; Pappalardo, L. Measuring objective and subjective well-being: Dimensions and data sources. Int. J. Data Sci. Anal. 2021, 11, 279-309. [CrossRef]

49. Tellier, L. The World Urban History; Presses Universitaires de Québec: Québec, QC, Canada, 2017.

50. Koglin, T. Sustainable Development in General and Urban Context: A Literature Review; Bulletin 248; Lund University, Lund Institute of Technology: Lund, Sweden, 2009.

51. Fusco, L.G.; Nijkamp, P.; Kourtit, K. Urban Transformation, Historic Districts and Waterfront Areas. Sustainability 2013, 6 , 4580-4586.

52. Nijkamp, P.; Kourtit, K.; Fusco, L.G. Cities as Sustainable Wealth Creators. Int. J. Sustain. Dev. 2013, 13, $2-4$.

53. Tellier, L.-N. Characterizing urban form by means of the Urban Metric System. Land Use Policy 2020, 2020, 104672. [CrossRef]

54. Toger, M.; Kourtit, K.; Nijkamp, P.; Östh, J. Mobility during the COVID-19 Pandemic: A Data-Driven Time-Geographic Analysis of Health-Induced Mobility Changes. Sustainability 2021, 13, 4027. [CrossRef]

55. Um, S.T.; Buzzard, J. Why Cities Matter, Why Cities Matter: To God, the Culture, and the Church; Crossway: Wheaton, IL, USA, 2013.

56. Combes, P.; Duranton, G.; Gobillon, L.; Puga, D.; Roux, S. The Productivity Advantages of Large Cities: Distinguishing Agglomeration From Firm Selection. Econometrica 2012, 80, 2543-2594.

57. Duranton, G.; Diego, P. Microfoundations of Urban Agglomeration Economies. In Handbook of Regional and Urban Economics; Henderson, V., François Thisse, J., Eds.; North-Holland: Amsterdam, The Netherland, 2004; Volume 4, pp. $2063-2117$.

58. Rosenthal, S.S.; Strange, W.C. Evidence on the Nature and Sources of Agglomeration Economies. In Handbook of Regional and Urban Economics; Henderson, V., Thisse, J.F., Eds.; North-Holland: Amsterdam, The Netherland, 2004; pp. $2119-2171$.

59. Melitz, M.; Gianmarco, I.; Ottaviano, P. Market Size, Trade and Productivity. Rev. Econ. Stud. 2008, 75, 295-316. [CrossRef]

60. Melo, P.; Graham, D.; Noland, R. A meta-analysis of estimates of urban agglomeration economies. Reg. Sci. Urban Econ. 2009, 39, 332-342. [CrossRef]

61. Smith, A. An Inquiry into the Nature and Causes of the Wealth of Nations; W. Strahan and T. Cadell in the Strand: London, UK, 1776.

62. Marshall, N. A Principles of Economics; Macmillan: London, UK, 1890.

63. Glaeser, E. Triumph of the City: How Our Greatest Invention Makes Us Richer, Smarter, Greener, Healthier, and Happier; Penguin Press: New York, NY, USA, 2011.

64. Jacobs, J. The Death and Life of Great American Cities; Vintage: New York, NY, USA, 1961.

65. Sassen, S. Cities: A Window into Larger and Smaller Worlds. Eur. Educ. Res. J. 2012, 11, 1-10. [CrossRef]

66. Lynch, K. The Image of the City; MIT Press: Cambridge, MA, USA, 1960.

67. Whyte, W.H. The Social Life of Small Urban Spaces; Conservation Foundation: Washington, DC, USA.

68. Gehl, J. Life between Buildings: Using Public Space; Arkitektens Forlag: Copenhagen, Denmark, 1987.

69. Montgomery, J. Making a city: Urbanity, vitality and urban design. J. Urban Des. 1998, 3, 93-116. [CrossRef]

70. Carmona, M. Public Places, Urban Spaces: The Dimensions of Urban Design; Architectural Press: Boston, MA, USA; Elsevier: Amsterdam, The Netherlands, 2010.

71. Myrick, P. The Power of Place: A New Dimension for Sustainable Development, Project for Public Spaces. 2011. Available online: https:/ / www.pps.org (accessed on 30 April 2011).

72. Marsden, T. Sustainable place-making for sustainability science: The contested case of agri-food and urban-rural relations. Sustain. Sci. 2013, 8, 213-226. [CrossRef]

73. Arefi, M. Deconstructing Placemaking: Needs, Opportunities, and Assets; Routledge: New York, NY, USA, 2014.

74. Donovan, M. Place Making and Sustainability; Epic: Advancing the Value of Ethnography in Business Series: 2017. Available online: https: / /www.epicpeople.org (accessed on 30 March 2017).

75. Kalandides, A. Citizen participation: Towards a framework for policy assessment. J. Place Manag. Dev. 2018, 11, 152-164. [CrossRef]

76. Ghavampour, E.; Vale, B. Revisiting the "Model of Place": A Comparative Study of Placemaking and Sustainability. Urban Plan. 2019, 4, 196-206. [CrossRef]

77. Jacobs, J. The Edge of Empire: Postcolonialism and the City; Routledge: London, UK, 1998.

78. Rapoport, A. The Meaning of the Built Environment: A Nonverbal Communication Approach; Sage Publications: Beverly Hills, CA, USA, 1982.

79. Devine-Wright, P. Think global, act local? The relevance of place attachments and place identities in a climate changed world. Glob. Environ. Chang. 2013, 23, 61-69. [CrossRef]

80. Jeon, M.; Shin, M.; Lee, S.J. An Analysis of Factors Influencing Individually-And Socially Oriented Happiness. Korean J. Pol. Stud. 2014, 29, 43-69. [CrossRef] 
81. Zenker, S.; Rütter, N. Is satisfaction the key? The role of citizen satisfaction, place attachment and place brand attitude on positive citizenship behavior. Cities 2014, 38, 11-17. [CrossRef]

82. Casakin, H.; Hernández, B.; Ruiz, C. Place attachment and place identity in Israeli cities: The influence of city size. Cities 2015, 42, 224-230. [CrossRef]

83. Westin, K. Place Attachment and Mobility in City Regions. Popul. Space Place 2016, 22, 722-735. [CrossRef]

84. Van Wessel, M. Citizens as Sense-Makers: Towards a Deeper Appreciation of Citizens' Understandings of Democratic Politics. Political. Stud. 2016, 65, 127-145. [CrossRef]

85. Jacobs, J. The Economy of Cities; Vintage: New York, NY, USA, 1969.

86. Kirk, W.; Lösch, A.; Berlin, I. Problems of Geography. Geography 1963, 48, 357-371.

87. Mason, R.; Canter, D. The Psychology of Place; Architectural Press: London, UK, 1977.

88. Schneekloth, L.H.; Shibley, R.G. Placemaking: The Art and Practice of Building Communities; Wiley: New York, NY, USA, 1995.

89. Sassen, S. The repositioning of citizenship and alienage: Emergent subjects and spaces for politics*. Globalizations 2005, 2, 79-94. [CrossRef]

90. Pierre, J. The Politics of Urban Governance; Palgrave Macmillan: London, UK, 2011.

91. Meijer, A. Smart City Governance: A Local Emergent Perspective. In Smarter as the New Urban Agenda; Public Administration and Information Technology; Gil-Garcia, J., Pardo, T., Nam, T., Eds.; Springer: Cham, Switzerland, 2016; pp. 73-85.

92. Miao, J.; McGill, W.L. Human-Centered Sensing for Crisis Response and Management Analysis Campaigns. In ISCRAM 2010-7th International Conference on Information Systems for Crisis Response and Management: Defining Crisis Management 3.0, Proceedings; 2010 Information Systems for Crisis Response and Management; Zobel, C., French, B.T.S., Eds.; ISCRAM: Seattle, WA, USA, 2010.

93. Craglia, M.; Ostermann, F.; Spinsanti, L. Digital Earth from vision to practice: Making sense of citizen-generated content. Int. J. Digit. Earth 2012, 5, 398-416. [CrossRef]

94. Dickinson, J.L.; Bonney, R. Citizen Science: Public Participation in Environmental Research; Comstock Publishing Associates: Ithaca, NY, USA, 2012.

95. Science Communication Unit. University of the West of England, Bristol, Science for Environment Policy, European Commission DG Environment, December 2013. Available online: https:/ / ec.europa.eu/environment/integration/research/newsalert/pdf/ IR9_en.pdf (accessed on 30 December 2013).

96. Bonney, R.; Cooper, C.B.; Dickinson, J.; Kelling, S.; Phillips, T.; Rosenberg, K.V.; Shirk, J. Citizen Science: A Developing Tool for Expanding Science Knowledge and Scientific Literacy. Bioscience 2009, 59, 977-984. [CrossRef]

97. Crall, A.W.; Newman, G.J.; Stohlgren, T.J.; Holfelder, K.A.; Graham, J.H.; Waller, D.M. Assessing citizen science data quality: An invasive species case study. Conserv. Lett. 2011, 4, 433-442. [CrossRef]

98. Branchini, S.; Meschini, M.; Covi, C.; Piccinetti, C.; Zaccanti, F.; Goffredo, S. Participating in a Citizen Science Monitoring Program: Implications for Environmental Education. PLoS ONE 2015, 10, e0131812. [CrossRef]

99. Craglia, M.; Granell, C. Citizen Science and Smart Cities; Publications Office of the European Union: Luxembourg, 2014; Available online: http:/ / publications.jrc.ec.europa.eu/repository/bitstream/JRC90374/lbna26652enn.pdf. (accessed on 20 February 2014).

100. Borsekova, K.; Nijkamp, P. Resilience and Urban Disasters; Edward Elgar Publishing: Cheltenham, UK, 2019.

101. Bănică, A.; Kourtit, K.; Nijkamp, P. Natural disasters as a development opportunity: A spatial economic resilience interpretation. Rev. Reg. Res. 2020, 40, 223-249. [CrossRef]

102. Sassen, S. Why Global Cities? In The Century of Global Cities: How Urbanisation Is Changing the World and Shaping our Future; Zevi, T., Ed.; Ledizioni Ledi Publishing: Milan, Italy, 2019; pp. 9-16. Available online: https://www.ispionline.it/sites/default/files/ pubblicazioni/ispiglobalcities_web2.pdf (accessed on 30 December 2019).

103. Couclelis, H. There will be no Post-COVID city. Environ. Plan. B Urban Anal. City Sci. 2020, 47, 1121-1123. [CrossRef]

104. Leinberger, C. Footloose and Fancy Free: A Field Survey of Walkable Urban Places in the Top 30 U.S. Metropolitan Areas; Brookings: Washington, DC, USA, 2007; Available online: www.brookings.edu/research/papers/2007/12/1128-walkableurbanism-leinberger (accessed on 30 December 2007).

105. UN Habitat. The City We Need; UN-Habitat: Nairobi, Kenya, 2016.

106. Batty, M. The New Science of the City; MIT Press: Cambridge, UK, 2013.

107. Vaz, E.; Cusimano, M.; Hernandez, T. Land use perception of self-reported health: Exploratory analysis of anthropogenic land use phenotypes. Land Use Policy 2015, 46, 232-240. [CrossRef]

108. Vaz, E.; Kourtit, K.; Nijkamp, P.; Painho, M. Spatial analysis of sustainability of urban habitats, introduction. Habitat Int. 2015, 45, 71. [CrossRef]

109. Montgomery, C. Happy City Transforming Our Lives Through Urban Desin; Farrar, Straus and Giroux: New York, NY, USA, 2013.

110. Warnick, M. This Is Where You Belong: Finding Home Wherever You Are; Penguin: New York, NY, USA, 2016. 